\title{
Introduction to Ethics of Forgiveness and Revenge
}

\author{
Krisanna M. Scheiter ${ }^{1}$
}

Received: 7 April 2016 /Accepted: 17 April 2016/

Published online: 23 June 2016

(C) Springer Science+Business Media Dordrecht 2016

\begin{abstract}
The papers collected in this volume were first presented at a workshop entitled Ethics of Forgiveness and Revenge, which was held May 22-23, 2014 at Union College in Schenectady, New York. The papers cover a range of topics, including the rightness and wrongness of vengeance and forgiveness, who has the standing to avenge or forgive, the relationship between retributive punishment and revenge, and the role apology plays in determining correct punishment. The papers in this volume are not only philosophically interesting, but are also relevant to our everyday lives, since how we respond to moral wrongs is just as important as how we conduct the rest of our moral lives.
\end{abstract}

The papers collected in this volume were first presented at a workshop entitled Ethics of Forgiveness and Revenge, which was held May 22-23, 2014 at Union College in Schenectady, New York. Authors were invited to expand on previously published work or present works-in-progress. The result is a rich and overlapping collection of papers that will serve both novices and veterans in the field.

The volume covers a wide variety of topics and in this short introduction I will focus on just a few themes. One common theme concerns the relationship between retributive punishment and revenge. In his paper, "Revenge as the Dark Double of Retributive Punishment," Whitley Kaufman argues against those who distinguish retributive punishment from revenge by claiming that retributive punishment is morally justified but revenge is not. Kaufman claims that revenge is actually the "dark double" of retributive punishment, insisting that at the end of the day they have "the same purpose, the same

\author{
Authors contributing to the volume include \\ Whitley Kaufman \\ Tamler Sommers \\ Nick Smith \\ Paul Hughes \\ Peter French
}

Krisanna M. Scheiter

scheitek@union.edu

1 Department of Philosophy, Union College, 807 Union Street, Schenectady, NY 12308, USA 
motivation, and the same moral justification" (Kaufman 2016). On his view, both revenge and retributive punishment aim at restoring the honor of victims of wrongdoing. In recognizing the similarities between revenge and retributive punishment, he claims that we force ourselves to address the moral justification of punishment as well as revenge.

Tamler Sommers also critiques retributive theories of punishment in his paper, "The Three Rs: Retribution, Revenge, and Reparation." He points out that "standard" models of retributive justice ignore "victims' attitudes, desires, and behavior," considering them to be largely irrelevant for determining just punishment (Sommers 2016). Those who defend the standard retributive model assume third party punishment restores victims' self-respect, but Sommers suggests that there is no evidence this in fact happens. He maintains that we actually strip victims of the opportunity to regain self-respect if we do not allow them to be involved in the process of punishing. He therefore argues for a restorative model of justice that would consider the interests of crime victims while still respecting societal order and rule of law as well as ensuring that we retain a commitment to proportionate punishments (Sommers 2016).

A second, related, theme concerns how we ought to respond to those who commit wrongs against us. In his paper, Nick Smith uses retributive principles to show that a specific kind of apology can warrant a reduction in punishment. He uses principles grounded in retributive theories of justice to show that "categorically apologetic offenders" deserve a reduction in punishment. In his paper Smith lists the conditions necessary for categorical apologies, which include among other things accepting blame, identifying the specific moral principles that have been violated, regret, and reform (Smith 2016). Smith argues that we must take into consideration the aftermath of a wrong. Doing so, he claims, is not a consequentialist idea, but a retributive idea. Part of what makes stealing so bad is the fact that the victim of the theft will feel unsafe in the future. A categorical apology can minimize the harm caused by the crime and should, therefore, reduce the punishment, according to Smith.

Revenge and punishment are not the only responses to wrongdoing, of course. In his paper, "Two Cheers for Forgiveness" Paul Hughes argues that there are several reasons for thinking interpersonal forgiveness is preferable to revenge as a response to wrongdoing. However, Hughes challenges what he calls the "Consensus View" of interpersonal forgiveness, broadening the scope of what counts as forgiveness. According to Hughes, the problem with the Consensus View is that it runs into a number of paradoxes due to unnecessary requirements. For example, the consensus view maintains that the forgiver must have the correct standing to forgive (Hughes 2015). Hughes claims the standing condition is arbitrary and there are no independent reasons for thinking only the victim of wrongdoing can forgive an offender. He points out that forgiving is at least in part defined as overcoming feelings of resentment, and so there does not appear to be a good reason to think only victims of wrongdoing can forgive an offender. Many people feel resentment towards wrongdoers even though they were not themselves wronged or victimized in any way.

Hughes expands the scope of who can forgive and under what conditions it is morally appropriate to forgive. He further argues that forgiveness is preferable to revenge, which he claims does not appear to have any real benefits. He points out that acts of revenge often lead to cycles of violence and those who seek revenge are typically left feeling unsatisfied or empty. Even if there are instances when forgiveness 
is not morally appropriate, there are other ways we can respond to wrongdoing, such as simply ignoring the offense. Given the shortcomings of revenge Hughes does not see many moral reasons for applauding revenge as morally good even if it turns out that revenge is not inherently morally bad as many authors in this volume claim. According to Hughes "we have sufficient experiential knowledge of forgiveness and revenge to be able to judge that the former is preferable to the latter. Even if there is something to be said in favor of revenge, morally speaking, forgiveness is commonly thought to be a morally superior way to respond to wrongdoing" (Hughes 2015).

Hughes' critique of revenge focuses on large scale, violent acts of vengeance. But Peter French argues in his paper, "Virtuous Avengers in Commonplace Cases," that many acts of revenge occur on a small scale and can have a positive impact on those who seek revenge. French claims that revenge "can be especially effectual in commonplace cases of perceived maltreatment, exploitation, oppression, neglect and the like that are under the radar of formal societal systems of justice" and even "play a positive role in strengthening the moral foundations of a community" (French 2016). French presents four conditions, which he lays out in his well-known book, The Virtues of Vengeance, that must be met in order for revenge to be virtuous. First, the offender must deserve to be punished. Second, the avenger must make sure the offender understands why she is being punished. Third, the penalty has to fit the perceived wrong. Fourth, the avenger must have the authority to exact vengeance upon the offender. Unlike Sommers, who claims that the victim must play a central role in bringing about the punishment, French maintains that victims do not hold any special claim to vengeance. On his view, third parties can exact revenge for a wrong so long as they use reliable epistemic measures to ensure that they punish the correct person and that the penalty fits the offense (French 2016).

The papers in this volume are part of an important and ongoing debate concerning the ethics of revenge and forgiveness, which is not only philosophically interesting, but also of pragmatic value. How we respond to moral wrongs is just as important as how we conduct the rest of our moral lives, making this topic worth special attention.

Krisanna M. Scheiter

Union College

\section{References}

French, P. A. (2016). Virtuous avengers in commonplace cases. Philosophia. doi:10.1007/s11406-016-9729-4. Hughes, P. M. (2015). Two cheers for Forgiveness (and even fewer for revenge). Philosophia. doi:10.1007/ s11406-015-9671-x.

Kaufman, W. R. (2016). Revenge as the Dark Double of Retributive Punishment. Philosophia. doi:10.1007/ s11406-015-9675-6.

Smith, N. (2016). Dialectical Retributivism: Why Apologetic Offenders Deserve Reductions in Punishment Even Under Retributive Theories. Philosophia. doi:10.1007/s11406-016-9695-x.

Sommers, T. (2016). The Three Rs: Retribution, Revenge, and Reparation. Philosophia. doi:10.1007/s11406016-9706-y. 